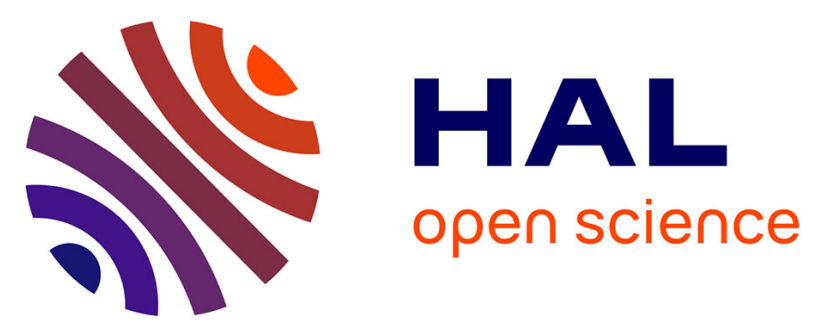

\title{
Zinc Sorption to Three Gram-Negative Bacteria: Combined Titration, Modeling, and EXAFS Study
}

Véronique Guiné, Lorenzo Spadini, Geraldine Sarret, Myriam Muris, Cécile Delolme, Jean-Paul Gaudet, Jean Martins

\section{- To cite this version:}

Véronique Guiné, Lorenzo Spadini, Geraldine Sarret, Myriam Muris, Cécile Delolme, et al.. Zinc Sorption to Three Gram-Negative Bacteria: Combined Titration, Modeling, and EXAFS Study. Environmental Science and Technology, 2006, 40 (6), pp.1806-1813. 10.1021/es050981l . hal-00191148

\author{
HAL Id: hal-00191148 \\ https://hal.science/hal-00191148
}

Submitted on 29 Nov 2007

HAL is a multi-disciplinary open access archive for the deposit and dissemination of scientific research documents, whether they are published or not. The documents may come from teaching and research institutions in France or abroad, or from public or private research centers.
L'archive ouverte pluridisciplinaire HAL, est destinée au dépôt et à la diffusion de documents scientifiques de niveau recherche, publiés ou non, émanant des établissements d'enseignement et de recherche français ou étrangers, des laboratoires publics ou privés. 


\title{
Zinc sorption to three Gram-negative bacteria: combined titration, modeling and EXAFS study
}

\author{
Guiné V. ${ }^{1}$, Spadini L. ${ }^{2}$, Sarret G. ${ }^{2}$, Muris M. ${ }^{3}$, Delolme C. ${ }^{3}$, Gaudet J-P. ${ }^{1}$, and Martins J.M.F. ${ }^{{ }^{*}}$ \\ ${ }^{1}$ Laboratoire d'Etudes des Transferts en Hydrologie et Environnement (LTHE-UMR \\ 5564) - Domaine Universitaire BP53 - 38041 Grenoble Cedex 9 - France. \\ 2 Environmental Geochemistry Group, Laboratoire de Géophysique Interne et \\ Tectonophysique (LGIT-UMR 5559) - Domaine Universitaire BP53 - 38041 \\ Grenoble Cedex 9 - France. \\ ${ }^{3}$ Laboratoire des Sciences de 1'Environnement (LSE) - E.N.T.P.E. - Rue Maurice \\ Audin - 69518 Vaulx-en-Velin Cedex - France. \\ *corresponding author: jean.martins@hmg.inpg.fr
}

\section{Abstract}

The acid-base and Zn sorption properties of three bacteria, Cupriavidus metallidurans $\mathrm{CH} 34$, Pseudomonas putida ATCC12633 and Escherichia coli K12DH5 $\alpha$, were investigated through an original combination of extended X-ray absorption fine structure (EXAFS) spectroscopy and equilibrium titrations studies. Acid-base titration curves of the three strains were fitted with a model accounting for three conceptual reactive sites: an acidic (carboxyl and/or phosphodiester), a neutral (phosphomonoester) and a basic (amine and/or hydroxyl) group. Calculated proton and $\mathrm{Zn}$ equilibrium constants and site densities compare with literature data. The nature of $\mathrm{Zn}$ binding sites was studied by EXAFS spectroscopy. Phosphoester, carboxyl, and unexpectedly sulfhydryl ligands were identified. Their proportions depended on $\mathrm{Zn}$ loading and bacterial strain, and were consistent with the titration results. These findings were compared to the structure and site density of the major cell wall components. It appeared that the cumulated theoretical site density of these structures $\left(<2 \mathrm{Zn} \mathrm{nm}^{-2}\right)$ is much lower than the total site density of the investigated strains $(16$ to $56 \mathrm{Zn} \mathrm{nm}$ ). These results suggest a dominant role of the extracellular polymeric substances in the $\mathrm{Zn}$ retention processes, although $\mathrm{Zn}$ binding to inner cell components cannot be excluded. 


\section{Introduction}

Many geochemical processes such as sorption, transformation, precipitation or dissolution of metallic trace elements are microbially mediated $(1,2)$. Studies dealing with the global transfer characteristics of metals in soils generally consider bacteria as basic biosorbent particles that may either favor the transfer of metals if they are mobile, or increase their retention if they form biofilms $(3,4)$. Such studies address the global reactivity of the bacterial substrate, which reveals generally dependent on $\mathrm{pH}$, redox potential and dissolved metal concentrations. In this respect, bacterial reactivity to metals is important to assess as it may control the distribution and transport of metals in the environment. Early research by Sherbert (5) or Beveridge and Murray ( 6 ) related the bacterial reactivity to the anionic character of specific functional groups situated on membrane components. These authors considered the major cell wall components (e.g. teichoic acids, peptidoglycan, (lipo)phospholipids) as principally responsible for the overall bacterial reactivity. The determined reactive anionic functional groups were essentially carboxyls (R-COOH), phosphomonoesters $\left(\mathrm{R}-\mathrm{OPO}_{3} \mathrm{H}_{2}\right)$, phosphodiesters $\left((\mathrm{RO})_{2}-\mathrm{P}(\mathrm{OH})_{2}\right)$, amines $\left(\mathrm{R}_{-} \mathrm{NH}_{3}{ }^{+}\right)$and hydroxyls $(\mathrm{R}-\mathrm{OH})$. On this basis, Fein et al. (7) developed a bacterial sorption model simplifying the variety of these groups to three main site groups differing in acid-base reactivity: acidic sites involving carboxyl and phosphodiester groups (pK <4.7), neutral sites involving phosphomonoester groups ( $\mathrm{pK}$ values $\approx 7$ ), and basic sites involving hydroxyl and amine groups $(\mathrm{pK}>8)$. Using this modeling approach, the reactivity of various heavy metals $(\mathrm{Cu}, \mathrm{Cd}, \mathrm{Zn}, \mathrm{Al}, \mathrm{Pb} \ldots .$.$) with numerous bacterial substrates was assessed (8,7,9-$ 14). Yee and Fein (11) found that the metal sorption capacity and reactivity of different grampositive and gram-negative bacteria roughly compare. This finding led them to develop a 'universal adsorption edge' model, which considers similar reactivity for all bacteria. Although helpful in practice, this approach appears surprising on a first view, specifically with regards to the different structures involved in the cell wall of gram-positive and Gram-negative bacteria. To validate this conceptualization, innovative approaches coupling macroscopic and microscopic studies are needed to assess both reactivity (affinity constants) and structure of reactive sites on bacterial membranes. To date, only few studies have combined such approaches on such materials (15-17).

The present work aims at determining the reactivity and nature of Zn-binding components of three gram-negative bacteria of environmental interest (Cupriavidus metallidurans CH34, Pseudomonas putida ATCC12633 and Escherichia coli K12DH5 $\alpha$ ). The 
surface reactivity of these bacteria was assessed macroscopically through proton exchange and zinc adsorption experiments and microscopically through $\mathrm{Zn}$ K-edge extended X-ray absorption fine structure (EXAFS) spectroscopy. These results are discussed in the light of the composition and structure of bacterial cell walls.

\section{Material and Methods}

\section{Bacterial cell preparation and growth}

Three rod-shaped gram-negative aerobic strains were investigated: the metal tolerant $C$. metallidurans $\mathrm{CH} 34$ (formerly Alcaligenes eutrophus CH34); a P. putida strain (ATCC12633) commonly found in natural environments and E. coli DH5 $\alpha$. Three minimum media were used for bacteria cultivation based on their nutritive specificity: a mineral salt medium (MSM) with $1 \mathrm{~g} \mathrm{~L}^{-1}$ acetate for $P$. putida, the M9 medium with $5 \mathrm{~g} \mathrm{~L}^{-1}$ glucose for $E$. coli, and TRIS salt medium (TSM) with $2 \mathrm{~g} \mathrm{~L}^{-1}$ gluconate for C. metallidurans. Compared to rich Luria Broth (LB), these mineral media ensure an improved reproducibility of acid-base titrations. The three bacterial strains were grown by shaking at $200 \mathrm{rpm}$ until the late exponential phase $\left(24 \mathrm{~h} / 30^{\circ} \mathrm{C}\right)$ for E. coli and C. metallidurans and to the stationary phase $\left(50 \mathrm{~h} / 23^{\circ} \mathrm{C}\right)$ for $P$. putida. The cells were then pelleted (9000 g), washed 3 times with ultrapure water and resuspended in $10 \mathrm{mM}$ $\mathrm{NaCl}$. Elemental analysis shows that the C:N:P:S elemental contents $(\% \pm$ SD of triplicate measurements) for the three strains compare within close limits: $\mathrm{C}=45.8 \pm 2.1 ; \mathrm{N}=12.0 \pm 0.9$; $\mathrm{P}=1.8 \pm 0.5$ and $\mathrm{S}=0.54 \pm 0.10$. The determination of cell concentrations is detailed in the Supporting Information. The geometric characteristics of the three strains (Table 1) were obtained from TEM observations (20 KeV, 10000 magnification).

\section{Acid-base titration experiments}

Acid-base titrations were performed in a closed vessel under $\mathrm{N}_{2}$ positive pressure. $50 \mathrm{ml}$ of bacterial suspensions of $2 \pm 0.4 \mathrm{~g}_{\mathrm{DW} \mathrm{L}} \mathrm{L}^{-1}$ were stirred and maintained at $4{ }^{\circ} \mathrm{C}$ (E. coli and $C$. metallidurans) or $20^{\circ} \mathrm{C}$ (P. putida). In the case of E. coli and C. metallidurans the potential of the $\mathrm{pH}$ electrode did not stabilize within a reasonable timescale at $20^{\circ} \mathrm{C}$, whereas at $4^{\circ} \mathrm{C}$ reproducible measurements were obtained. Titrations were performed from the equilibrium $\mathrm{pH}$ of cell suspensions ( $\mathrm{pH} 5$ to 7) towards $\mathrm{pH} 4$ or 10 adding strong acid or base stepwise, 
respectively. This procedure avoids irreversible effects on bacteria such as cell aggregation and membrane denaturizing. The data treatment was based on the proton mass balance:

$$
\left[H^{+}\right]=\frac{v_{0}\left[H_{I}\right]}{v_{0}+v}+\frac{v\left[H_{B}\right]}{v_{0}+v}+\frac{v_{0}\left[H_{S}\right]}{v_{0}+v}+\left[O H^{-}\right]
$$

where: $\left[H^{+}\right]$the free proton concentration; $\left[H_{I}\right]$ the analytically known initial concentration of strong acid (positive) or base (negative) added to the reactor; $\left[H_{B}\right]$ the burette strong acid (positive) or base (negative) concentration; $\left[H_{S}\right]$ the experimentally assessed concentration of protons released from the weak ligand (i.e. the bacterial substrate); $\left[\mathrm{OH}^{-}\right]$the protons generated from water dissociation; $v_{0}$ the initial reactor volume and $v$ the burette volume added to reactor. A detailed description is provided in the Supporting Information.

Titration reversibility was studied in duplicate for $P$. putida (data not shown) assuming a similar behavior of the other two bacteria. After completion of each half-titration, a second titration was performed in the opposite $\mathrm{pH}$ direction by adding strong acid or base depending on the end $\mathrm{pH}$ of the first titration (4 or 10). A good agreement (less than $5 \%$ difference) between up and down titrations was observed, indicating a complete reversibility of proton exchange, as demonstrated by several other works $(7,18,9,11)$. Cell viability performed after each titration experiments revealed always over $70 \%$ survivals.

\section{Acid-base titration modeling}

In modeling three acid-base exchange sites were discriminated within the investigated $\mathrm{pH}$ range following Fein et al. (7), noted:

(1) Acidic site:

$\equiv \mathrm{COOH} \leftrightarrow \equiv \mathrm{COO}^{-}+\mathrm{H}^{+}$

$2 \leq \mathrm{pK}_{\mathrm{x}-\mathrm{CH}} \leq 6 ; \quad\left[\mathrm{T}_{\mathrm{x}-\mathrm{CH}}\right] ;$

(2) Neutral site:

$\equiv \mathrm{POH} \leftrightarrow \equiv \mathrm{PO}^{-}+\mathrm{H}^{+}$;

$5.7 \leq \mathrm{pK}_{\mathrm{x}-\mathrm{PH}} \leq 7.2 ; \quad\left[\mathrm{T}_{\mathrm{x}-\mathrm{PH}}\right]$;

(3) Basic site:

$\equiv \mathrm{NH}^{+} \leftrightarrow \equiv \mathrm{N}+\mathrm{H}^{+} ;$

$8 \leq \mathrm{pK}_{\mathrm{x}-\mathrm{NH}} \leq 12 ; \quad\left[\mathrm{T}_{\mathrm{x}-\mathrm{NH}}\right]$.

They are respectively representative for carboxyl and phosphodiester (1), phosphomonoester (2) and hydroxyl and amine (3) functional groups, with $\mathrm{x}=\mathrm{CM}$ for $C$. metallidurans, $\mathrm{x}=\mathrm{EC}$ for E. coli, and $\mathrm{x}=\mathrm{PP}$ for $P$. putida. $\left[\mathrm{T}_{\mathrm{x}-\mathrm{CH}}\right],\left[\mathrm{T}_{\mathrm{x}-\mathrm{PH}}\right]$ and $\left[\mathrm{T}_{\mathrm{x}-\mathrm{NH}}\right]$ refer to the total concentrations of these respective sites. The sum of the three terms expresses the total proton exchange capacity of the bacterial strain. A detailed description of the modeling approach is given in the Supporting Information. GRFIT (19), a non-electrostatic model was used to model equilibrium data. This FITEQL substitute enables a visual comparison of fitted and experimental data. In agreement with Fein et al. (14) who showed that acid-base titrations of Bacillus subtilis did not 
allow the discrimination of surface electrostatic effects, our analysis was based on a nonelectrostatic model, which is a simplification of the real processes.

\section{Zn sorption and EXAFS spectroscopy}

Equilibrium zinc sorption studies were performed at $4^{\circ} \mathrm{C}$ in stirred closed vessels $(40 \mathrm{ml})$, $I=10 \pm 1(\mathrm{mM})(\mathrm{i})$ at fixed total $\mathrm{Zn}$ concentration $\left(\left[\mathrm{T}_{\mathrm{Zn}}\right]=40,160\right.$ or $\left.900 \mu \mathrm{M}\right)$ and varying $\mathrm{pH}$ (from 3.5 to 8.5 ) in triplicates and (ii) at fixed $\mathrm{pH}(3.7 \pm 0.1 ; 5.8 \pm 0.1$, or $7.8 \pm 0.1$ ) and varying [ $\left.\mathrm{T}_{\mathrm{Zn}}\right]$ (from 1.5 to $760 \mu \mathrm{M}$ ) in duplicate. During the $24 \mathrm{~h}$ equilibration time, small aliquots of acid or base were added when necessary to maintain the initial $\mathrm{pH}( \pm 0.1)$. The vessel opening time was minimized to limit $\mathrm{CO}_{2}$ intrusion. Control vessels without bacteria were prepared to account for precipitation and/or vial adsorption. Dissolved Zn was quantified by ICP AES (Perkin-Elmer, Optima 3300 DV). The PhreeqC code (20) was used to model zinc sorption.

EXAFS Zn samples were prepared by equilibrating bacterial suspensions at different total biomass concentrations $\left[\mathrm{T}_{\mathrm{B}}\right]$ for $24 \mathrm{~h}$ with two $\left[\mathrm{T}_{\mathrm{Zn}}\right]$ (high and low $\mathrm{Zn}$ concentrations, Table 2). After equilibrium, suspension $\mathrm{pH}$ was measured, and the cells were centrifuged at $9000 \mathrm{~g}$.

Considering the low $\mathrm{Zn}$ content of some of the samples (down to $2.3 \mu \mathrm{mol} \mathrm{g}_{\mathrm{DW}}{ }^{-1}$ ), it was not possible to record them in hydrated state. For homogeneity between samples, all of them were recorded in freeze-dried state. Pokrovsky et al. (21) did not observe any difference in $\mathrm{Zn}$ speciation between fresh and freeze-dried diatoms. The effect of freeze-drying on $\mathrm{Zn}$ speciation was not evaluated, but the redistribution of $\mathrm{Zn}$ on different binding sites is unlikely since (i) the removal of water molecules takes place in frozen state and (ii) the cells were not rehydrated thereafter. The bacterial pellets were instantly frozen by plunging the tubes in liquid nitrogen, freeze-dried (Christ, Osterode am Harz, Germany, $-52{ }^{\circ} \mathrm{C}, 0.2$ mbar), pressed as pellets, and stored in a dry atmosphere before EXAFS measurement. Zn K-edge EXAFS spectra for the bacteria were measured at $100 \mathrm{~K}$ on the FAME beamline at the European Synchrotron Radiation Facility (ESRF, Grenoble, France) in fluorescence mode using a 30element solid-state Ge detector (Canberra) for the diluted samples, and in transmission mode using a diode for the most concentrated samples. EXAFS data extraction was done according to standard methods, and EXAFS analysis was performed by linear combinations fits and by standard FEFF simulation for the first shell, as detailed in the Supporting Information. 


\section{Results}

\section{Surface proton exchange}

The acid-base titration curves of the three bacteria are presented in Figure 1. The amount of protons exchanged between $\mathrm{pH} 4$ and $\mathrm{pH} 10$, defined as $\Delta[\mathrm{Hs}]$, is $0.99,0.52$ and $1.2 \mathrm{mmol} \mathrm{g}_{\mathrm{DW}}{ }^{-}$

${ }^{1}$ for $C$. metallidurans, E. coli and P. putida, respectively. Thus, the proton sorption capacity of the three strains compares within a factor of 2.3 in this $\mathrm{pH}$ range.

The curve for P. putida presents three steps in the acidic (4 to 5.5), neutral (6.4 to 7.5) and basic (8.5 to 10$) \mathrm{pH}$ ranges, respectively, attesting for the existence of at least three proton exchanging functional groups. For the two other bacteria, no particular change of slope is observed between $\mathrm{pH} 5.3$ to 8.3 , but $\Delta\left[H_{S}\right]$ is still significant within these $\mathrm{pH}$ limits. Indeed, $\Delta\left[H_{S}\right]$ between $\mathrm{pH} 5.3$ to 8.3 equals $0.15 \mathrm{mmol} / \mathrm{g}_{\mathrm{DW}}$ for both bacteria, which represents $15 \%$ and $29 \%$ of $\Delta\left[H_{S}\right]$ exchanged between $\mathrm{pH} 4$ and $\mathrm{pH} 10$ for $C$. metallidurans and E. coli, respectively. This indicates that a neutral proton exchanger also exists for these bacteria. Outside the 4 to $10 \mathrm{pH}$ range, the slopes of the three curves are not null, indicating that proton exchange reactions occur outside the experimentally available $\mathrm{pH}$ range, and involving an underestimation of the effective total site concentration of acidic and basic groups. Thus, the total proton exchange capacity is higher than the one calculated from the $\mathrm{pH} 4$ to $10 \Delta\left[H_{S}\right]$ reading. $\mathrm{pK}$ PP-PH situates at the inflexion point around $\mathrm{pH}$ 7. The $\Delta\left[H_{S}\right]$ reading between $\mathrm{pH} 6$ and 8 is thus an approximation of phosphomonoester total sites concentration ([ $\left.\mathrm{T}_{\mathrm{x}-\mathrm{PH}}\right]$ in mmol $\mathrm{g}_{\mathrm{DW}}{ }^{-1}$ ) of the three bacteria: $\left[\mathrm{T}_{\mathrm{PP}-\mathrm{PH}}\right] \cong 0.32,\left[\mathrm{~T}_{\mathrm{CM}-\mathrm{PH}}\right] \cong 0.12$ and $\left[\mathrm{T}_{\mathrm{EC}-\mathrm{PH}}\right] \cong 0.07$. Solid lines in Figure 1 are the best fits obtained for these data and the corresponding $\mathrm{pK}$ and $[\mathrm{T}]$ parameters are given in Table 1. $\left[\mathrm{T}_{\mathrm{x}-\mathrm{PH}}\right]$ was first optimized and then held constant during adjustments of the five remaining variables. The uncertainties on $\mathrm{pK}_{\mathrm{x}-\mathrm{PH}}$ and $\left[\mathrm{T}_{\mathrm{x}-\mathrm{PH}}\right]$ are relatively low $( \pm 0.2$ Log units and $\pm 10 \%$, respectively) and the fitted $\mathrm{pK}_{\mathrm{x}-\mathrm{PH}}$ values for the three bacteria are close (Table 1). Obviously, $\mathrm{pK}$ and $[\mathrm{T}]$ uncertainties for acidic $(\mathrm{x}-\mathrm{CH})$ and basic sites $(\mathrm{x}-\mathrm{NH})$ are higher ( \pm 0.8 Log units and $\pm 30 \%$, respectively), since data are not available at extreme $\mathrm{pH}$. Both $\mathrm{pK}$ and $[\mathrm{T}]$ values compare to previously published data, such as for a Enterobacteriaceae sp. strain (12), which develops site densities of $0.50 \pm 0.07 ; 0.22 \pm 0.06$ and $0.55 \pm 0.02 \mathrm{mmol}_{\mathrm{DW}^{-1}}$ for carboxyl and phosphodiester (pK $4.3 \pm 0.2$ ), phosphomonoester (pK $6.9 \pm 0.5)$ and hydroxyl and amine (pK $8.9 \pm 0.5)$ sites. Close values were also observed for Picocyanobacteria (13) 0.26-0.74 (pK 4.8-5.0); 0.19-0.44 (pK 6.6-6.7) 
and 0.25-0.48 mmol $\mathrm{g}_{\mathrm{DW}}{ }^{-1}$ (pK 8.8-8.7). Yee and Fein (11) found higher total site concentrations for their series of gram-negative and gram-positive bacteria: 0.9-3.1 (pK 5.0 \pm 0.2 ), 0.4-1.4 (pK 7.2) and 0.6-2.9 mmol $\mathrm{g}_{\mathrm{DW}}{ }^{-1}$ (pK 9.7). Contrarily, Haas et al. (9) measured lower site densities for Shewanella putrefaciens: 0.03 (pK $5.16 \pm 0.04), 0.01$ (pK $7.22 \pm 0.15$ ) and $0.04 \mathrm{mmol} \mathrm{g}_{\mathrm{DW}}^{-1}$ (pK $\left.10.04 \pm 0.67\right)$.

\section{Zinc sorption}

Zinc sorption isotherms are presented in Figure 2. As expected, $\left[\mathrm{Zn}_{\mathrm{ads}}\right]$ increases with $\mathrm{pH}$ and $\mathrm{Zn}$ in solution $\left(\left[\mathrm{Zn}_{\mathrm{aq}}\right]\right)$. For all three bacteria (Fig. $\left.2 \mathrm{~A}\right)$ and at three different $\mathrm{pH}$ (Fig. 2B), the $\left[\mathrm{Zn}_{\mathrm{ads}}\right]$ versus $\left[\mathrm{Zn}_{\mathrm{aq}}\right]$ curve slope decreases progressively when increasing $\left[\mathrm{Zn}_{\mathrm{aq}}\right]$, suggesting a gradual saturation of surface reactive sites. Figure $2 \mathrm{~A}$ shows that at constant $\mathrm{pH}(5.8 \pm 0.1)$, the cell reactivity to $\mathrm{Zn}$ follows the order $P$. putida $\cong E$. coli $>C$. metallidurans, within a 1 Log unit difference in reactivity. At high $\mathrm{Zn}$ loading this difference tends to decrease, suggesting similar Zn-total site concentrations. Zinc sorption isotherms at varying $\mathrm{pH}$ are given in Figure 3. At $\mathrm{pH} 5.8 \pm 0.1$ and comparable total zinc $\left[\mathrm{T}_{\mathrm{Zn}}\right]$ and biomass $\left[\mathrm{T}_{\mathrm{B}}\right]$ concentrations, E. coli sorbs about 3 to 4 times more zinc than C. metallidurans, as already observed in Figure 2A.

The PhreeqC code was used to model zinc sorption, assuming that the sorption is reversible (7, $9,11,18)$ and that metals compete with protons on acid-base reactive sites. A 1:1 stoichiometric ratio is considered for complex interactions of cations with bacterial sites:

$$
\begin{array}{llll}
\text { Acidic site: } & \equiv \mathrm{COO}^{-}+\mathrm{Zn}^{2+} & \leftrightarrow \equiv \mathrm{COOZn}^{+} ; & \operatorname{LogK}_{\mathrm{x}-\mathrm{CZn}} \\
\text { Neutral site: } & \equiv \mathrm{PO}^{-}+\mathrm{Zn}^{2+} & \leftrightarrow \equiv \mathrm{POZn}^{+} ; & \operatorname{LogK}_{\mathrm{x}-\mathrm{PZn}} \\
\text { Basic site: } & \equiv \mathrm{N}+\mathrm{Zn}^{2+} & \leftrightarrow \equiv \mathrm{NZn}^{+2} ; & \operatorname{LogK}_{\mathrm{x}-\mathrm{NZn}}
\end{array}
$$

Commonly, it is considered that basic hydroxyl and amine sites do not significantly contribute to cation adsorption. The present dataset covers relatively large $\mathrm{pH}(3.5$ to 8.5$)$ and $\left[\mathrm{Zn}_{\mathrm{aq}}\right]\left(10^{-}\right.$ 5.8 to $10^{-3.0} \mathrm{~mol} \mathrm{~L}^{-1}$ ) ranges. Considering only $\mathrm{Zn}$ sorption on $\equiv \mathrm{POH}$ and $\equiv \mathrm{COOH}$ sites, it was not possible to fit the gap between isotherms at $\mathrm{pH} 5.8$ and 7.8 (Fig. 2B). These sites are deprotonated at high $\mathrm{pH}$, meaning that metal adsorption is $\mathrm{pH}$ independent. Thus if complexation on basic sites is not considered, the fitted curves at $\mathrm{pH} 5.8$ and 7.8 almost overlap. Independent experiments lasting for $24 \mathrm{~h}$ (data not shown) revealed sorption to be relatively fast ( $<1$ hour), suggesting negligible sorption kinetics. The introduction of basic $\mathrm{Zn}$ complexation sites leads to an adequate data fit for C. metallidurans (Fig. 2B). On this basis, we also considered $\mathrm{Zn}$ complexation on the three functional groups for the $E$. coli and $P$. 
putida datasets. $\log \mathrm{K}_{\mathrm{PP}-\mathrm{NZn}}$ and $\log \mathrm{K}_{\mathrm{PP}-\mathrm{PZn}}$ constants were set as close as possible to those of C. metallidurans and E. coli.

The distribution of $\mathrm{Zn}$ sorption sites can be assessed from the model curves given in Figure $2 \mathrm{C}$. This speciation scheme relates to the largest $C$. metallidurans dataset and is considered also conceptually valid for the two other bacteria. At low $\mathrm{pH}$, the acidic $\equiv \mathrm{COOH}$ site is the dominant $\mathrm{Zn}$ complexing group (Fig. 2C, left). At intermediate $\mathrm{pH}$ (5.8), the dominant complexing group depends on surface coverage (Fig. 2C, center): at low surface coverage, most $\mathrm{Zn}$ is bound to the $\equiv \mathrm{POH}$ site (phosphomonoester groups), but this site of relatively low total concentration is rapidly saturated, and the excess $\mathrm{Zn}$ is then complexed to acidic carboxyl groups. At pH 7.8 the basic $\equiv \mathrm{NH}^{+}$site is the only and dominant $\mathrm{Zn}$ sorbent (Fig. $2 \mathrm{C}$, right).

\section{EXAFS analysis}

Zn K-edge EXAFS spectroscopy was applied to independently characterize the Zn-binding sites, using low and high $\mathrm{Zn}$ concentration samples for the three bacteria (position of the EXAFS samples on the $\mathrm{Zn}$ adsorption isotherms shown in Fig. 2A). The spectra for the most concentrated samples (P. putida, $362 \mu \mathrm{mol} \mathrm{g}_{\mathrm{DW}}{ }^{-1} \mathrm{Zn}$; E. coli, $108 \mu \mathrm{mol} \mathrm{g}_{\mathrm{DW}}{ }^{-1} \mathrm{Zn}$; C. metallidurans, $10.8 \mu \mathrm{mol} \mathrm{gDW}^{-1} \mathrm{Zn}$ ) contain a dominant single frequency typical of $\mathrm{Zn}$ bound to oxygen-containing ligands as found in $\mathrm{Zn}$ malate (ligand/metal $\mathrm{L} / \mathrm{M}$ molar ratio $=8$ ) and/or Zn-zorbed hydroxylapatite (Fig. 4). The spectra for the most diluted $\mathrm{Zn}$ samples $(C$. metallidurans, $2.9 \mu \mathrm{mol} \mathrm{g}_{\mathrm{DW}}{ }^{-1} \mathrm{Zn}$ and E. coli, $2.3 \mu \mathrm{mol} \mathrm{g}_{\mathrm{DW}}{ }^{-1} \mathrm{Zn}$ ) are not in phase with the previous ones. Particularly, their second and third oscillation maxima are slightly shifted to lower wave numbers (left and middle vertical lines in Fig. 4). These shifts are in line with the corresponding oscillation maxima for $\mathrm{Zn}$ cysteine $(\mathrm{L} / \mathrm{M}=5)$. However, the fourth oscillation maximum for the $\mathrm{Zn}$ cysteine reference is not visible on the bacterial spectra (right vertical line in Fig. 4). It is possible that the combination of $\mathrm{Zn}-\mathrm{S}$ and $\mathrm{Zn}-\mathrm{O}$ contributions cancel each other around $9.1 \AA$ in these low $\mathrm{Zn}$ concentration bacterial samples. The spectrum for P. putida, 5.9

$\mu \mathrm{mol} \mathrm{g}_{\mathrm{DW}}{ }^{-1} \mathrm{Zn}$ is intermediate between these two categories. These spectra were simulated by linear combination fits (LCFs, Fig. 4 and Table 2) using a library of $\mathrm{Zn}$ reference spectra including simple compounds (i.e., $\mathrm{Zn}$ complexed to simple organic acids) and complex structures (i.e., Zn bound to a distribution of carboxyl and hydroxyl sites). The references and their significance are given in the Supporting Information. Simulations using simple compounds yielded unsatisfactory results, and best fits were obtained with two- to threecomponent combinations of Zn-sorbed hydroxylapatite, Zn-humic acid complex and Zn- 
cysteine, $\mathrm{L} / \mathrm{M}=5$ references. In the first reference, $\mathrm{Zn}$ is bound to phosphate surface sites (23). This spectrum is poorly structured, suggesting multiple and/or disordered $\mathrm{Zn}$ local environments. The $\mathrm{Zn}$ phosphomonoester reference $\mathrm{Zn}$ phytate provided weaker fits, and $\mathrm{Zn}$ phosphodiester structures were not tested. However, EXAFS spectroscopy is probably not sensitive enough to distinguish between phosphate, phosphomonoester and phosphodiester ligands in complex systems since the nature of the $\mathrm{Zn}$ nearest and next-nearest neighbors would be identical ( $\mathrm{O}$ and $\mathrm{P}$, respectively). Thus, this mineral reference is considered as a proxy for a distribution of phosphoesters groups of different geometries. Humic acids contain a distribution of carboxyl, phenol and hydroxyl sites. At the $\mathrm{pH}$ used for standards and bacterial samples preparation (below 6.5), phenol and hydroxyl sites are not deprotonated. Therefore, the second reference can be equated to a distribution of $\mathrm{Zn}$-carboxyl sites. In the third reference (Zn-cysteine, $\mathrm{L} / \mathrm{M}=5$ ), the metal is bound to sulfhydryl and carboxyl and/or amine ligands. No good simulations were obtained with $\mathrm{ZnS}$ or with the other $\mathrm{Zn}$-cysteine reference $(\mathrm{L} / \mathrm{M}=$ 10) in which $\mathrm{Zn}$ is bound to sulfhydryl ligands only. This suggests the presence of mixed environment in the bacterial cell walls, with $\mathrm{Zn}$ bound to sulfhydryl and carboxyl and/or amine ligands. LCFs results (Table 2) show that $\mathrm{Zn}$ phosphoesters complexes predominate in all samples except $C$. metallidurans, $10.8 \mu \mathrm{mol} \mathrm{Zn} \mathrm{g}_{\mathrm{DW}}{ }^{-1}$ and $P$. putida, $362 \mu \mathrm{mol} \mathrm{Zn} \mathrm{gDw}^{-1}$ which contain equivalent amounts of Zn-carboxyl and Zn-phosphoester complexes. The fits indicate that $\mathrm{Zn}$-cysteine type environments are present in C. metallidurans and E. coli at low $\mathrm{Zn}$ loading, but they are not detected at higher Zn loading. They are probably still present, but representing less than 5-10\% of total $\mathrm{Zn}$ due to the predominance of $\mathrm{Zn}$-carboxyl and $\mathrm{Zn}$ phosphoester complexes. Sulfhydryl ligands are not detected in P. putida samples. Considering that the $\mathrm{S}$ total contents are comparable for the three bacteria (see Materials and Methods), the accessibility of $\mathrm{Zn}$ to sulfur groups decreases in the order $C$. metallidurans $\gg$ E. coli $>>P$. putida $(\sim 0)$ in our experimental conditions.

The structure of the first coordination shell was studied in more details by FEFF simulations (Table 2 and Fig. S3 in Supporting Information). The results show the presence of 2.5 and 1.5 sulfur atoms in the coordination sphere of $\mathrm{Zn}$ for $C$. metallidurans and E. coli at low $\mathrm{Zn}$ loading, respectively, the rest being oxygen atoms. A simple calculation (see Supporting information) shows that sulfur atoms bound to $\mathrm{Zn}$ represent 4.3 and $2.1 \%$ of the total $\mathrm{S}$ content, respectively. Compared to the estimated total ion exchange capacity of the bacteria

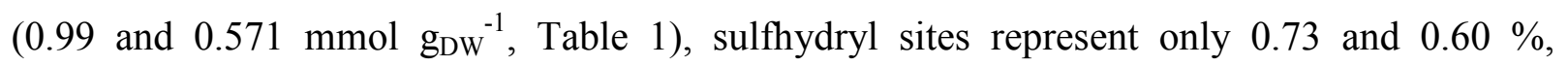
respectively. Therefore these sites cannot be taken into account in the titration experiments. 
In the other samples, oxygen is the only $\mathrm{Zn}$ neighbor. $\mathrm{Zn}-\mathrm{O}$ distances range between 1.97 and $2.02 \AA$, which suggests a mixture of tetrahedral and octahedral environments (24). These distances should be considered with care since the freeze-drying treatment might modify the geometry of the $\mathrm{Zn}$ local environment (by removing some water molecules), although, the nature of the $\mathrm{Zn}$ binding groups should not be affected (see Materials and Methods). The simulation of the second shell did not yield satisfactory fits, probably because of the presence of mixed-types of $\mathrm{Zn}$ ligands. Therefore, in order to determine the most probable configuration of $\mathrm{Zn}$ in our samples, a screening of known structures in which $\mathrm{Zn}$ is bound to phosphoester and carboxyl groups (Cambridge Structural Database, www.ccdc.cam.ac.uk) was realized. For $\mathrm{P}$ ligands, $\mathrm{Zn}$ is bound to only one oxygen atom of the phosphate group (monodentate) in 99\% of the structures, and to two oxygen atoms of the same phosphate group (bidentate) in the last percent. Similarly, for carboxyl ligands, $\mathrm{Zn}$ is bound to one oxygen atom of the $\mathrm{COOH}$ group (monodentate) in $90 \%$ of the structures, and bidentate in the last $10 \%$. Therefore, the corner sharing configuration for $\mathrm{Zn}-\mathrm{P}$ sites and monodentate $\mathrm{Zn}-\mathrm{COOH}$ bonds are the most likely.

The identification of phosphoester and carboxyl groups as $\mathrm{Zn}$ binding sites are in agreement with previous works on similar systems (17). To our knowledge, Zn-sulfhydryl interactions are evidenced for the first time in bacterial samples. Also, the order of Zn affinity: sulfhydryl > phosphoester $>$ carboxyl obtained from EXAFS compares with the titration results: phosphoester $>$ carboxyl (sulfhydryl sites are not detectable in titration experiments). This is in agreement with a previous study showing a higher affinity of $\mathrm{Zn}$ for phosphate than for carboxyl groups in Penicillium chrysogenum (24).

\section{Discussion}

At pH 5.8, the maximum measured $\mathrm{Zn}$ loadings for the three bacteria are about $0.2 \mathrm{mmol} \mathrm{g}_{\mathrm{DW}}{ }^{-1}$ (Figures 2 and 3). Using the cell geometric data from Table 1, the corresponding calculated site densities are 31, 56 and $16 \mathrm{Zn} \mathrm{nm}^{-2}$, for E. coli, C. metallidurans and P. putida, respectively. Reactive site densities measured on minerals are much smaller: in the 1 to $4 \mathrm{Zn} \mathrm{nm}{ }^{-2}$ range. Geometrically it is not possible, for steric reasons, to adsorb on a surface more than $4 \mathrm{Zn} \mathrm{nm}^{-2}$ without forming polynuclear complexes (25). Thus, $\mathrm{Zn}$ ions sorbed on biomass are undoubtedly localized in different layers or even in different compartments. To validate this $\mathrm{Zn}$ distribution over the modeled sites, we investigated the theoretical reactivity of the major cell wall components, based on the assumption that each acid-base reactive group in these 
structures fixes one $\mathrm{Zn}$ atom. The well characterized membrane structure of E. coli was used as a model for the membranes of the studied bacteria (Figure 5).

First, lipopolysaccharides (LPS) are chain molecules evolving from the outer membrane composed of two parts in E. coli, a common lipid A base to which links a strain-specific polysaccharide containing reactive phosphomonoester and carboxyl groups (26). The lipid A contains hydrophilic chains attached to two esterified glucosamines, each linked to a reactive phosphomonoester $\equiv \mathrm{OPO}_{3} \mathrm{H}_{2}$ functional group (Figure 5). The polysaccharide chains of $E$. coli DH5 $\alpha$ (this study) contains 10 sugars with 5 phosphomonoester and 2 carboxyl groups. Thus, 7 $\mathrm{Zn}$ atoms may be fixed along a LPS unit, which covers approximately $50 \mathrm{~nm}^{2}$ of the membrane surface (R. Geremia, personal communication). The calculated site density thus equals $0.14 \mathrm{Zn}$ $\mathrm{nm}^{-2}$. Obviously, LPS cannot account for the measured $\mathrm{Zn}$ load. Moreover, the carboxyl groups contained in O-Antigens (present in other gram-negative bacteria) are not zinc and proton reactive (27).

Second, phospholipids are composed of two hydrophobic hydrocarbon chains bound to a glycerol unit to which is attached a hydrophilic head group. The E. coli head group is composed of phosphatidyl ethanolamine containing two acid-base reactive sites (amine and phosphodiester group; Fig. 5), thus two Zn atoms may be fixed. One phospholipid unit accounting for approximately $5 \mathrm{~nm}^{2}$, the maximal site density is $0.4 \mathrm{Zn} \mathrm{nm}$, much higher than the LPS site density $\left(0.14 \mathrm{Zn} \mathrm{nm}{ }^{-2}\right)$. Therefore, the latter is not further considered and the membrane is assumed as composed of four superimposed phospholipid layers. On this basis, i.e., considering that one functional group fixes one $\mathrm{Zn}$ atom, the calculated total $\mathrm{Zn}$ sorption capacity is $1.6 \mathrm{Zn} \mathrm{nm}$. Binder and Zschörnig (28) have shown by IR spectroscopy on synthetic lipids that $\mathrm{Zn}$ cations may bridge two or more phospholipids. Such stoichiometric relations would lead to an even lower $\mathrm{Zn}$ sorption capacity. In summary, the sorption capacity of LPS and phospholipids cannot account by far for the measured high $\mathrm{Zn}$ load (16 to $56 \mathrm{Zn}$ $\mathrm{nm}^{-2}$ ). Thus, further components must be taken into account in the cell membrane reactivity estimate including the peptidoglycan (PG) network and the exopolysaccharides (EPS).

Third, the PG network is situated in the periplasmic space. This rigid structure is composed of two sugar molecules linked to a tetrapeptide (Fig. 5), which contains three reactive carboxyl and one amine groups. The terminal D-alanine carboxyl group (pK 2.4) forms the interpeptide bound to the amine group of the meso-diaminopimelic acid and is consequently considered not Zn-reactive. However, the D-glutamic acid (pK 4.1) and the meso-diaminopimelic carboxyls may potentially exchange two protons and fix two $\mathrm{Zn}$ atoms. Considering an area of $10 \mathrm{~nm}^{2}$ for 
one PG unit, $0.2 \mathrm{Zn} \mathrm{nm}^{-2}$ may be linked to one sheet of PG leading to a theoretical maximum membrane reactivity of $1.8 \mathrm{Zn} \mathrm{nm}^{-2}$, still far from the measured $\mathrm{Zn}$ load.

Fourth, the most external cell wall component is the exopolysaccharides (EPS) layer that forms a capsule around the bacteria. In E. coli, it consists in long sugar chains, containing K-Antigens whose synthesis is enhanced under stress such as starvation or toxic environmental conditions (29) and colanic acid, and candidate $\mathrm{Zn}$ binding sites are essentially carboxyl groups. However, these EPS may retain various molecules exuded by the bacteria including nucleic acids, proteins, polysaccharides and lipids (30), thus forming the so-called extracellular polymeric substances $\left(\right.$ EPS $^{\text {bis }}$ ), which may strongly increase the sorption capacity of bacteria. Matsukawa et al. (31) showed that the EPS ${ }^{\text {bis }}$ of Pseudomonas aeruginosa biofilms contained up to $80 \%$ of nucleic acids. Although EPS ${ }^{\text {bis }}$ of planktonic bacteria are known to be less developed, the presence of nucleic acids may contribute to the pool of phosphoester groups evidenced by EXAFS and titrations, the amount of which cannot be explained by the other cell wall components. Sulfhydryl groups identified by EXAFS may belong to proteins of the inner or outer membranes, and/or to S-containing compounds possibly present in the EPS ${ }^{\text {bis }}$.

In conclusion, extracellular polymeric substances of the Gram-negative bacteria studied here play a dominant role in $\mathrm{Zn}$ retention processes as compared to the other membrane cell components. Besides $\mathrm{Zn}$ binding to the EPS ${ }^{\text {bis }}$, the entry of $\mathrm{Zn}$ inside the cells and binding to intracellular components cannot be excluded. However, this phenomenon is probably limited since metal sorption on bacteria in similar conditions has been often shown to be reversible ( 7 , 18, 9, 11). Further spectroscopic and thermodynamic characterization of isolated extracellular and intracellular compartments should help to better evaluate their respective role in metal retention by microorganisms

\section{Acknowledgements}

This research was supported by the "Programme National Sols et Erosion", ACI "Ecologie Quantitative", and ADEME. The authors acknowledge the ESRF for the provision of beamtime, Nicolas Geoffroy and Olivier Proux for assistance during EXAFS measurements, and S. Beauchemin and F. Panfili for Zn reference spectra. They also thank Benjamin Causse, Roberto Geremia and Jeremy Fein for fruitful discussions and Max Mergeay and Jacques Covès. 


\section{Supporting Information Available (SI)}

Experimental and modeling procedures of the titration study, as well as the EXAFS data analysis, with a description of thedatabase used to fit the data. This material is available free of charge via the Internet at http://pubs.acs.org.

\section{References}

(1) Ehrlich, H. L. Microbes and metals. Appl. Microbiol. Biotechnol. 1997, 48, 687-692.

(2) Ledin, M. Accumulation of metals by microorganisms - processes and importance for soil systems. Earth Sci. Rev. 2000, 51, 1-31.

(3) Guiné, V.; Martins, J.; Gaudet, J. P. Facilitated transport of heavy metals by bacterial colloids in sand columns. Journal De Physique IV 2003, 107, 593-596.

(4) Muris, M.; Delolme, C.; Gaudet, J. P.; Spadini, L. Assessment of biofilm destabilisation and consequent facilitated zinc transport. Water Sci. Technol. 2005, 51, 21-28.

(5) Sherbert, G. V. The Biophysical Characterisation of the Cell Surface; Academic Press: London, 1978.

(6) Beveridge, T. J.; Murray, R. Sites of metal deposition in the cell wall of Bacillus subtilis. J. Bact. 1980, 141, 876-887.

(7) Fein, J. B.; Daughney, C.; Yee, N.; Davis, T. A. A chemical equilibrium model for metal adsorption onto bacterial surfaces. Geochim. Cosmochim. Acta 1997, 61, 3319-3328.

(8) Plette, A. C. C.; Benedetti, M. F.; Van Riemsdijk, W. H. Competitive binding of protons, calcium, cadmium and zinc to isolated cell walls of a gram-positive soil bacterium. Environ. Sci. Technol. 1996, 30, 1902-1910.

(9) Haas, J. R.; Dichristina, T. J.; Wade, R. J. Thermodynamics of U(VI) sorption onto Shewanella putrefaciens. Chem. Geol. 2001, 180, 33-54.

(10) Sokolov, I.; Smith, D.; Henderson, G.; Gorby, Y.; Ferris, F. Cell surface electrochemical heterogeneity of the Fe(III)-reducing bacteria Shewanella putrefaciens. Environ. Sci. Technol. 2001, 35, 341-347.

(11) Yee, N.; Fein, J. B. Cd adsorption onto bacterial surfaces: a universal adsorption edge ? Geochim. Cosmochim. Acta 2001, 65, 2037-2042.

(12) Ngwenya, B. T.; Sutherland, I. W.; Kennedy, L. Comparison of the acid-base behaviour and metal adsorption characteristics of a gram-negative bacterium with other strains. Applied Geochemistry 2003, 18, 527-538. 
(13) Dittrich, M.; Sibler, S. Cell surface groups of two picocyanobacteria strains studied by zeta potential investigations, potentiometric titration, and infrared spectroscopy. J. Coll. Interf. Sci. 2005, 286, 487-495.

(14) Fein, J. B.; Boily, J.-F.; Yee, N.; Gorman-Lewis, D.; Turner, B. F. Potentiometric titrations of Bacillus subtilis cells to low $\mathrm{pH}$ and comparison of modelling approaches. Geochim. Cosmochim. Acta 2005, 69, 1123-1132.

(15) Kelly, S. D.; Kemner, K. M.; Fein, J. B.; Fowle, D. A.; Boyanov, M. I.; Bunker, B. A.; Yee, N. X-ray absorption fine structure determination of $\mathrm{pH}$-dependent U-bacterial cell wall interactions. Geochim. Cosmochim. Acta 2002, 66, 3855-3871.

(16) Boyanov, M. I.; Kelly, S. D.; Kemner, K. M.; Bunker, B. A.; Fein, J. B.; Fowle, D. A. Adsorption of cadmium to Bacillus subtilis bacterial cell walls: A pH-dependent X-ray absorption fine structure spectroscopy study. Geochim. Cosmochim. Acta 2003, 67, 32993311 .

(17) Toner, B.; Manceau, A.; Marcus, M. A.; Millet, D. B.; Sposito, G. Zinc sorption by a bacterial biofilm. Environmental Science and Technology 2005, 39, 8288-8294.

(18) Fowle, D. A.; Fein, J. B. Competitive adsorption of metal cations onto two gram positive bacteria: Testing the chemical equilibrium model. Geochimica et Cosmochimica Acta 1999, 63, 3059-3067.

(19) Ludwig, C. "GRFIT: A program for solving speciation problems, evaluation of equilibrium constants, concentrations and their physical parameters" Univ. of Berne, 1992.

(20) Parkhurst, D. L.; Appelo, C. A. J. User's guide to PhreeqC (version 2) A computer program for speciation batch-reaction, one dimensional transport and inverse geochemical calculations. Water Resour. Investig. Rep. 1999, 99, 4259.

(21) Pokrovsky, O. S.; Pokrovski, G. S.; Gelabert, A.; Schott, J.; Boudou, A. Speciation of Zn associated with diatoms using X-ray absorption spectroscopy. Environ. Sci. Technol. 2005, 39, 4490.

(22) Fein, J. B.; Martin, A. M.; Wightman, P. G. Metal adsorption onto bacterial surfaces: Development of a predictive approach. Geochim. Cosmochim. Acta 2001, 65, 4267-4273.

(23) Panfili, F.; Manceau, A.; Sarret, G.; Spadini, L.; Kirpichtchikova, T.; Bert, V.; Laboudigue, A.; Marcus, M.; Ahamdach, N.; Libert, M. The effect of phytostabilization on $\mathrm{Zn}$ speciation in a dredged contaminated sediment using scanning electron microscopy, X-ray fluorescence, EXAFS spectroscopy and principal components analysis. Geochim. Cosmochim. Acta 2005, 69, 2265-2284. 
(24) Sarret, G.; Manceau, A.; Spadini, L.; Roux, J. C.; Hazemann, J. L.; Soldo, Y.; EybertBérard, L.; Menthonnex, J. J. EXAFS determination of $\mathrm{Pb}, \mathrm{Zn}$ complexing sites of Penicillium chrysogenum cell walls. Environ. Sci. Technol. 1998, 32, 1648-1655.

(25) Spadini, L.; Schindler, P. W.; Charlet, L.; Manceau, A.; Ragnarsdottir, K. V. Hydrous ferric oxide: evaluation of Cd-HFO surface complexation models combining $\mathrm{Cd}-\mathrm{K}$ EXAFS data, potentiometric titration results, and surface site structures identified from mineralogical knowledge. J. Colloid Interface Sci. 2003, 266, 1-18.

(26) Kramer, R. A.; Brandenburg, K.; Vandeputte-Rutten, L.; Werkhoven, M.; Gros, P.; Dekker, N.; Egmond, M. R. Lipopolysaccharide regions involved in the activation of Escherichia coli outer membrane protease OmpT. Eur. J. Biochem. 2002, 269, 17461752.

(27) Kadrmas, J. L.; Raetz, C. R. H. Enzymatic synthesis of lipopolysaccharide in Escherichia coli. J. Biol. Chem. 1998, 273, 2799-2807.

(28) Binder, H.; Zschörnig, O. The effect of metal cations on the phase behavior and hydration characteristics of phospholipid membranes. Chem. Phy. Lipids 2002, 39-61.

(29) Whitfield, C.; Roberts, I. Structure, assembly and regulation of expression of capsules in Escherichia coli. Mol. Microbiol. 1999, 31, 1307-1319.

(30) Wingender, J.; Neu, T.; Flemming, H., Eds. Microbial Extracellular Polymeric Substances - Characterization, Structure and Function; Springer Verlag, 1999.

(31) Matsukawa, M.; Greenberg, E. P. Putative exopolysaccharide synthesis genes influence Pseudomonas aeruginosa biofilm development. J. Bact. 2004, 186, 4449-4456.

\section{BRIEF:}

Results of combined EXAFS spectroscopy, proton and $\mathrm{Zn}$ titrations studies of three gramnegative bacteria show that $\mathrm{Zn}$ is fixed by $\mathrm{P}, \mathrm{COOH}$ and newly identified $\mathrm{S}$ groups, and suggest a major role of the extracellular polymeric substances in $\mathrm{Zn}$ sorption. 
Table 1: Main characteristics of the bacterial strains

\begin{tabular}{|c|c|c|c|c|c|c|c|c|c|c|c|c|c|}
\hline & \multicolumn{3}{|c|}{ Enumeration $^{2}$} & \multicolumn{3}{|c|}{ Cell geometry $^{3}$} & \multirow[t]{2}{*}{ IEP $^{4}$} & \multicolumn{3}{|c|}{ Proton exchange $e^{1,5,6}$} & \multicolumn{3}{|c|}{ Zn exchange $^{6}$} \\
\hline & $\begin{array}{l}\text { nb. of cells } \\
\text { cells } g_{D W}{ }^{-1} \\
\pm 20 \%\end{array}$ & $\begin{array}{l}\text { biomass } \\
\mathrm{g}_{\mathrm{DW}} \mathrm{OD}_{600}{ }^{-1} \mathrm{~L}^{-1} \\
\pm 20 \%\end{array}$ & $\begin{array}{l}\text { protein } \\
\text { g cells }^{-1} \\
\pm 20 \%\end{array}$ & $\begin{array}{c}\text { length } \\
\mu \mathrm{m} \\
\pm 10 \%\end{array}$ & $\begin{array}{c}\text { diameter } \\
\mu \mathrm{m} \\
\pm 10 \%\end{array}$ & $\begin{array}{l}\text { surface } \\
\qquad \mathrm{m}^{2} \\
\pm 10 \%\end{array}$ & & $\begin{array}{l}\mathrm{pK}_{\mathrm{x}-\mathrm{CH}} \\
{\left[\mathrm{T}_{\mathrm{x}-\mathrm{CH}}\right]}\end{array}$ & $\begin{array}{l}\mathrm{pK}_{\mathrm{x}-\mathrm{PH}} \\
{\left[\mathrm{T}_{\mathrm{x}-\mathrm{PH}}\right]}\end{array}$ & $\begin{array}{l}\mathrm{pK}_{\mathrm{x}-\mathrm{NH}} \\
{\left[\mathrm{T}_{\mathrm{x}-\mathrm{NH}}\right]}\end{array}$ & $\operatorname{LogK}_{x-C Z n}$ & $\log K_{x-P Z n}$ & $\operatorname{LogK}_{\mathrm{x}-\mathrm{NZn}}$ \\
\hline C. metallidurans & $1.22 .10^{12}$ & 0.30 & -- & 1.2 & 0.4 & 1.76 & 3.5 & $3.8 ; 0.42$ & $6.7 ; 0.12$ & $9.4 ; 0.45$ & 2.0 & 4.0 & 5.2 \\
\hline E. coli & $8.55 .10^{11}$ & 0.45 & -- & 2.1 & 0.6 & 4.52 & 3.3 & $4.6 ; 0.25$ & $6.8 ; 0.071$ & $9.2 ; 0.25$ & 3.3 & 5.3 & 6.5 \\
\hline P. putida & $1.21 .10^{12}$ & -- & $4.510^{-13}$ & 3.0 & 0.6 & 6.22 & 3.5 & $4.4 ; 0.53$ & $6.5 ; 0.32$ & $9.7 ; 0.73$ & 2.2 & 4.6 & 5.6 \\
\hline
\end{tabular}

${ }^{1}[\mathrm{~T}]$ in mmol $\mathrm{gDw}^{-1},{ }^{2}$ Uncertainties correspond to $\pm \mathrm{SD}$ (rounded up) calculated from 5 independent replications. ${ }^{3} \mathrm{Obtained}$ from TEM (20 KeV, $\mathrm{x} 10000$ ) observations of fresh cells, considering a cylindrical shape of the cells. ${ }^{4} \mathrm{IEP}=\mathrm{pH}$ of isoelectric point (details on electrophoretic mobility measurements given in the Supporting Information). ${ }^{5}$ Conditional constants: at $4{ }^{\circ} \mathrm{C}$ (except for $P$. putida proton exchange data: $20^{\circ} \mathrm{C}$ ) in $10 \mathrm{mM}$ $\mathrm{NaCl} .{ }^{6}$ Uncertainties are \pm 0.2 for $\mathrm{pK}_{\mathrm{x}-\mathrm{PH}}, \pm 0.8$ for $\mathrm{pK}_{\mathrm{x}-\mathrm{CH}}$ and $\mathrm{pK}_{\mathrm{x}-\mathrm{NH}}, \pm 10 \%$ for $\left[\mathrm{T}_{\mathrm{x}-\mathrm{PH}}\right]$, and $\pm 30 \%$ for $\left[\mathrm{T}_{\mathrm{x}-\mathrm{CH}}\right]$ and $\left[\mathrm{T}_{\mathrm{x}-\mathrm{NH}}\right]$. 
Table 2: EXAFS results for bacterial samples and $\mathrm{Zn}$ reference compounds

\begin{tabular}{|c|c|c|c|c|c|c|c|c|c|c|c|c|c|c|}
\hline \multirow[t]{2}{*}{ Strain or sample ${ }^{1}$} & \multicolumn{4}{|c|}{ Sample characteristics } & \multicolumn{5}{|c|}{$\begin{array}{l}\text { First shell structural } \\
\text { parameters }^{2}\end{array}$} & \multicolumn{5}{|c|}{$\begin{array}{l}\text { Proportion (\%) for each type of ligand } \\
\text { determined by LCFs }\end{array}$} \\
\hline & $\begin{array}{c}\mathrm{pH} \\
( \pm 0.1)\end{array}$ & $\begin{array}{l}{\left[\mathrm{T}_{\mathrm{B}}\right],} \\
\mathrm{g} \mathrm{L}^{-1}\end{array}$ & $\begin{array}{c}{\left[\mathrm{Zn}_{\mathrm{ads}}\right]} \\
\mu \mathrm{mol} \mathrm{g}_{\mathrm{DW}}{ }^{-1}\end{array}$ & $\begin{array}{r}{\left[\mathrm{Zn}_{\mathrm{aq}}\right]} \\
\mu \mathrm{mol} \mathrm{L} \\
-1\end{array}$ & Atom & $C N$ & $R(\AA)$ & $\begin{array}{c}\sigma^{2} \\
\left(\AA^{2}\right)\end{array}$ & NSS & $\begin{array}{c}\text { Zn-sorbed } \\
\text { hydroxyl- } \\
\text { apatite }\end{array}$ & $\begin{array}{c}\mathrm{Zn-} \\
\text { humic } \\
\text { acid }\end{array}$ & $\begin{array}{c}\mathrm{Zn-} \\
\text { cysteine } \\
(\mathrm{L} / \mathrm{M}=5)\end{array}$ & Sum & NSS \\
\hline \multirow[t]{2}{*}{ C. metallidurans } & 6.5 & 2.5 & 2.9 & 4.0 & $\mathrm{O}$ & 2.8 & 1.97 & 0.010 & 1.0 & $61 \pm 6$ & 0 & $49 \pm 5$ & 110 & 5.7 \\
\hline & & & & & $\mathrm{S}$ & 2.5 & 2.31 & 0.010 & & & & & & \\
\hline C. metallidurans & 4.8 & 1.2 & 10.8 & 1150 & $\mathrm{O}$ & 5.6 & 1.98 & 0.009 & 1.4 & $54 \pm 10$ & $57 \pm 7$ & 0 & 111 & 3.6 \\
\hline \multirow[t]{2}{*}{ E. coli } & 6.4 & 4.0 & 2.3 & 1.9 & $\mathrm{O}$ & 3.1 & 1.97 & 0.009 & 1.0 & $81 \pm 7$ & $19 \pm 14$ & $8 \pm 6$ & 108 & 4.6 \\
\hline & & & & & $\mathrm{S}$ & 1.5 & 2.28 & 0.010 & & & & & & \\
\hline E. coli & 5.6 & 7.7 & 108 & 331 & $\mathrm{O}$ & 5.1 & 1.97 & 0.008 & 1.3 & $88 \pm 9$ & $24 \pm 9$ & 0 & 112 & 4.1 \\
\hline P. putida & 6.5 & 1.7 & 5.9 & 1.2 & $\mathrm{O}$ & 6.0 & 2.02 & 0.005 & 2.0 & $72 \pm 4$ & $32 \pm 4$ & 0 & 104 & 3.7 \\
\hline P. putida & 5.6 & 2.5 & 362 & $\approx 3200$ & $\mathrm{O}$ & 5.1 & 1.98 & 0.010 & 1.4 & $59 \pm 20$ & $44 \pm 19$ & 0 & 103 & 3.1 \\
\hline \multirow{2}{*}{$\begin{array}{l}\text { Zn cysteine } \\
(\mathrm{L} / \mathrm{M}=5)\end{array}$} & & & & & $\mathrm{O}$ & 1.4 & 1.99 & 0.010 & 0.7 & & & & & \\
\hline & & & & & $\mathrm{S}$ & 3.3 & 2.32 & 0.010 & & & & & & \\
\hline $\begin{array}{l}\text { Zn cysteine } \\
(\mathrm{L} / \mathrm{M}=10)\end{array}$ & & & & & $\mathrm{S}$ & 4.5 & 2.35 & 0.007 & 1.2 & & & & & \\
\hline
\end{tabular}

${ }^{1}$ The bacterial samples were recorded in freeze-dried state. ${ }^{2} C N$ : Coordination number; $R$ : Interatomic distance $(\AA) ; \sigma^{2}$ : Debye-Waller disorder factor $\left(\AA^{2}\right)$, Residual: $N S S=\Sigma\left[\mathrm{k}^{3} \chi(\mathrm{k})_{\exp }-\mathrm{k}^{3} \chi(\mathrm{k})_{\mathrm{fit}}\right]^{2} / \Sigma\left[\mathrm{k}^{3} \chi(\mathrm{k})_{\exp }\right]^{2} 100$. For the first shell simulations, an amplitude reduction factor $\left(\mathrm{S}_{0}^{2}\right)$ of 0.9 was used for all fits. Estimated errors on $R$ and $C N$ are $0.02 \AA$ and $20 \%$, respectively. ${ }^{3}$ The proportions of the ligands are given as mean $\pm \mathrm{SD}$ obtained from the best simulations. $\mathrm{L} / \mathrm{M}$ corresponds to the ligand/metal molar ratio used to prepare the reference compounds (see Supporting Information). 


\section{FIGURE CAPTIONS}

Figure 1: Acid-base titration curves for C. metallidurans, E. coli and P. putida. Symbols and solid lines refer to measured and calculated data, respectively (Table 1).

Figure 2: A) Calculated (solid lines, model parameters are given in Table 1) and measured $\mathrm{Zn}$ sorption isotherms at $\mathrm{pH} 5.8$ for C. metallidurans, E. coli and P. putida. Black symbols refer to low and high $\mathrm{Zn}$ concentration EXAFS samples: $\mathrm{pH}$, biomass $\left[\mathrm{T}_{\mathrm{B}}\right]\left(\mathrm{g} \mathrm{L}^{-1}\right)$ and total $\mathrm{Zn}$ concentration $\left[\mathrm{T}_{\mathrm{Zn}}\right](\mathrm{mM})$ of these samples are $4.8 \pm 0.1,1.2 \pm 0.1,1.2 \pm 0.2$ and $6.5 \pm 0.1,2.5 \pm 0.2,0.010 \pm 0.001$ for $C$. metallidurans and $5.6 \pm 0.1,7.7 \pm 0.8,1.2 \pm 0.2$ and $6.5 \pm 0.1,4.0 \pm 0.4,0.010 \pm 0.001$ for $E$. coli and $5.6 \pm 0.1,2.5 \pm 0.2,4.1 \pm 0.4$ and $6.4 \pm 0.1$, $1.7 \pm 0.2,0.010 \pm 0.001$ for $P$. putida. B) Measured and calculated Zn sorption isotherm for C. metallidurans at $\mathrm{pH} 3.7,5.8$ (similar to Fig. 2A) and 7.8. C) Calculated $\mathrm{Zn}$ distributions for phosphoester $\left(\equiv \mathrm{POZn}^{+}\right.$, thin black lines), carboxyl $\left(\equiv \mathrm{COOZn}^{+}\right.$, grey lines) and amine ( $\equiv \mathrm{NZn}^{+2}$ dotted lines) sorption sites plotted at $\mathrm{pH} 3.7$ (left), 5.8 (center) and 7.8 (right) using C. metallidurans constants. The sum of the three contributions (thick black line) represents the total sorbed $\mathrm{Zn}$ curve such as presented in Figure 2A and 2B. Note that the chosen axes and units ( $\mathrm{mol} \mathrm{g}_{\mathrm{DW}}{ }^{-1}$ versus mol $\mathrm{L}^{-1)}$ are permitted to fit the data independently from biomass concentration.

Figure 3: E. coli and C. metallidurans Zn-sorption experiments performed at varying $\mathrm{pH}$. Calculated solid lines refer to full symbol data and calculated dashed lines refer to empty symbol data. Note that for clarity only data obtained at $\left[\mathrm{T}_{\mathrm{Zn}}\right] 0.04$ and $0.18 \mathrm{mmol} \mathrm{L}^{-1}$, for C. metallidurans, are presented. Data at $0.9 \mathrm{mmol} \mathrm{L}^{-1}$ were not presented but were similarly well fitted. Note that modeling depends on biomass concentrations in this representation $\left([\mathrm{Zn}]_{\text {ads }} \mathrm{vs} \mathrm{pH}\right)$.

Figure 4: EXAFS spectra for the freeze-dried Zn-sorbed bacteria and Zn reference compounds (see Supporting Information). Dotted lines represent linear combination fits. The proportions of $\mathrm{Zn}$ species are given in Table 2.

Figure 5: Schematic representation of the major reactive components of $E$. coli cell wall (adapted from Kadrmas et al. (26) and Kramer et al. (27)). 


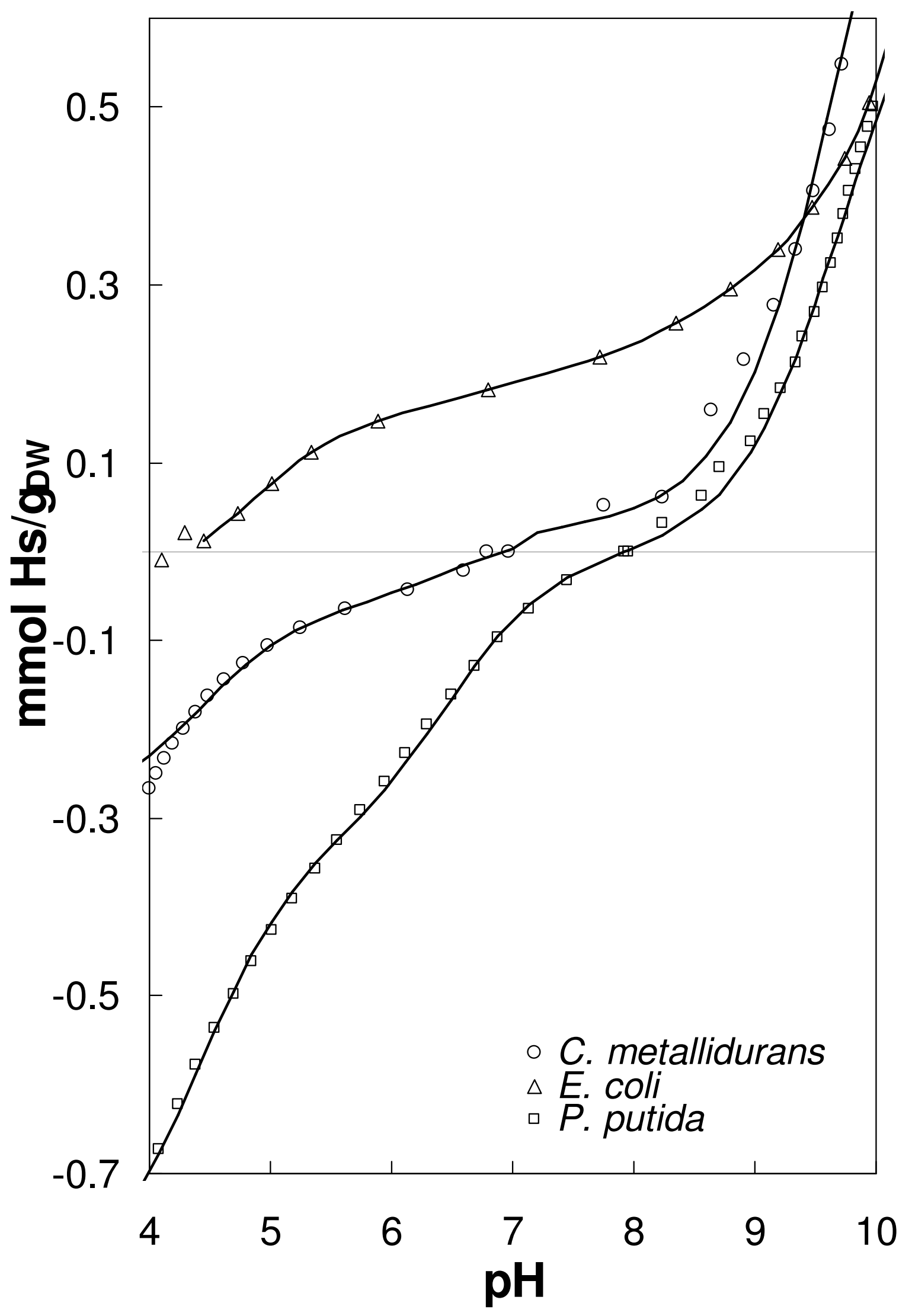

FIGURE 1 

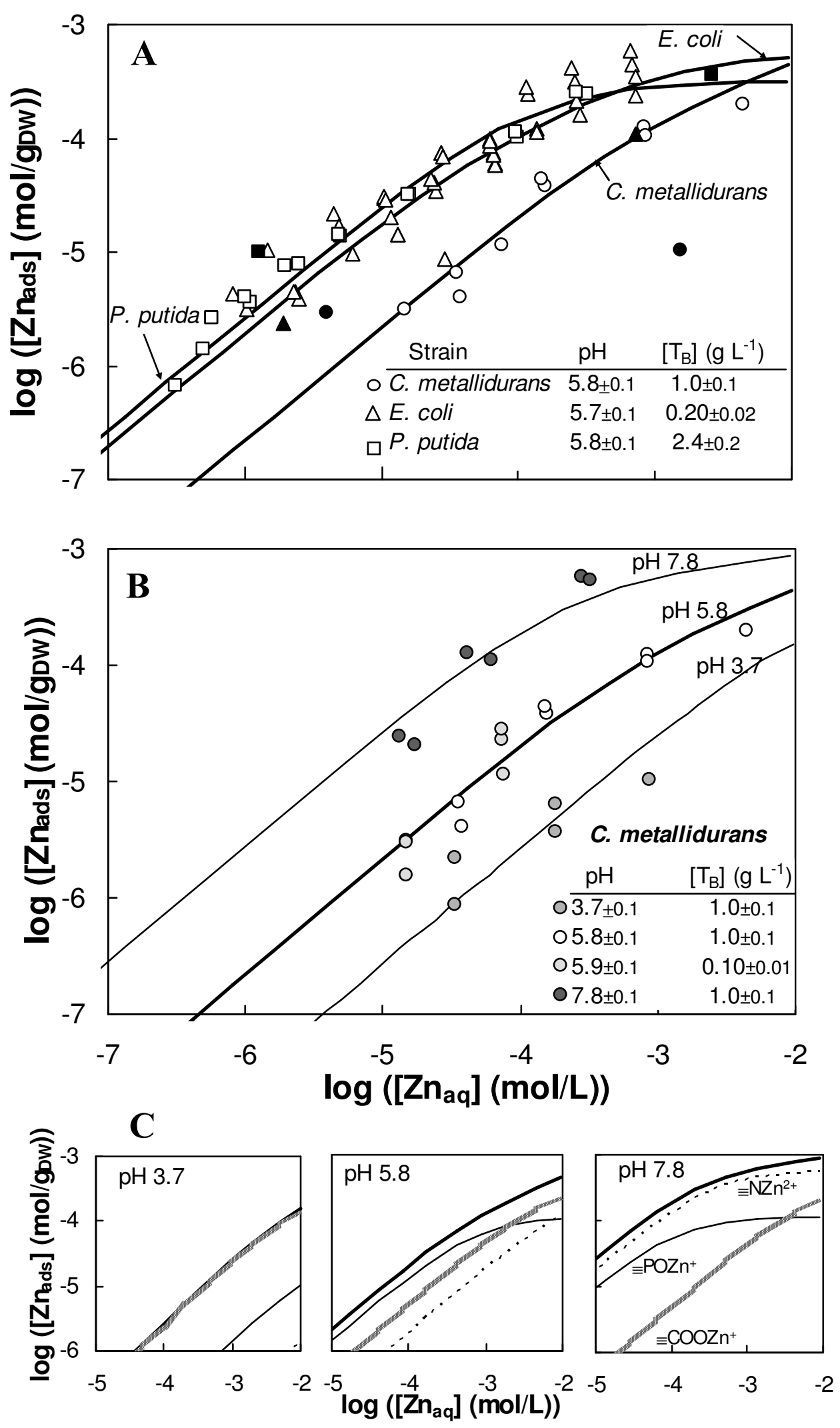

FIGURE 2 


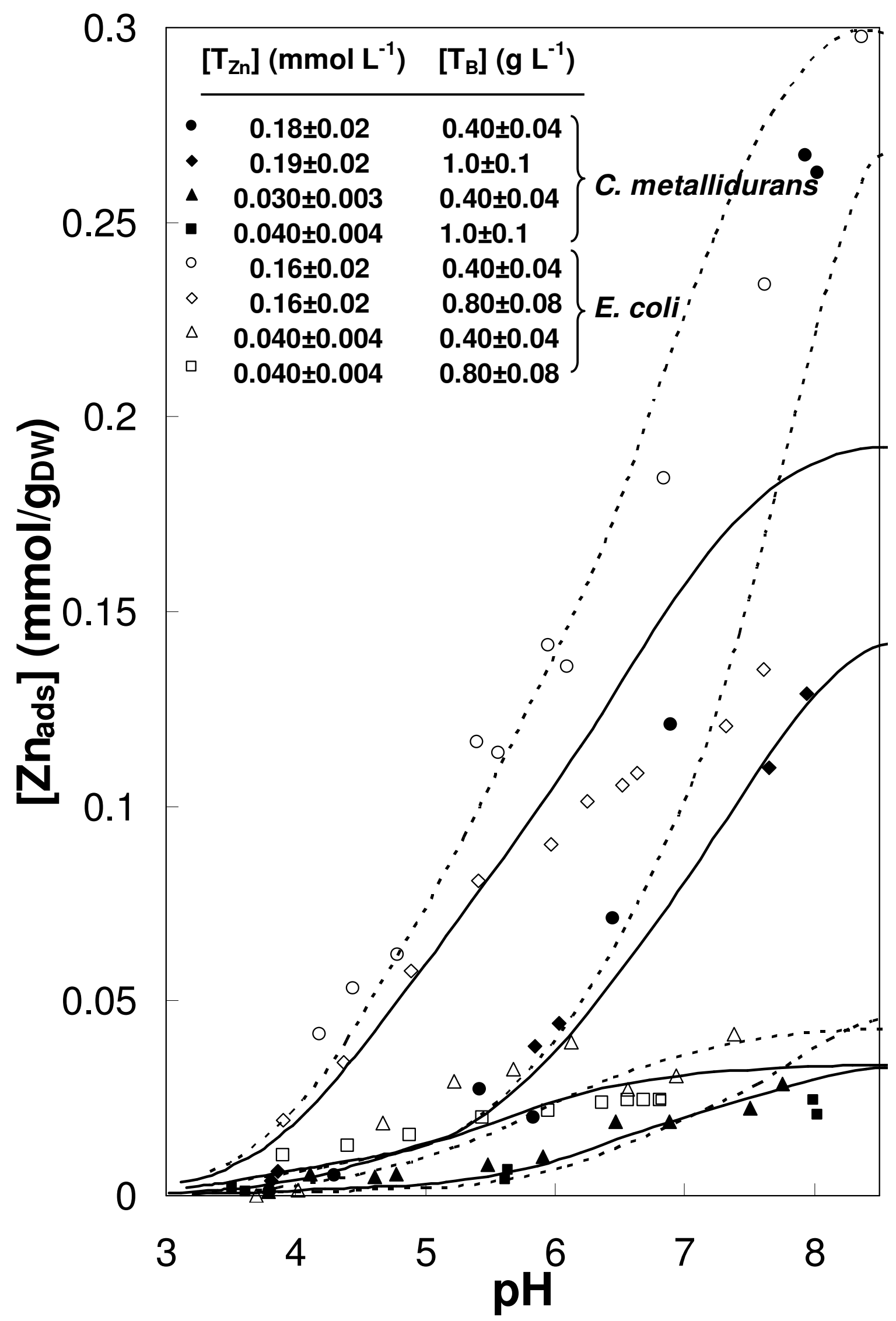

FIGURE 3 


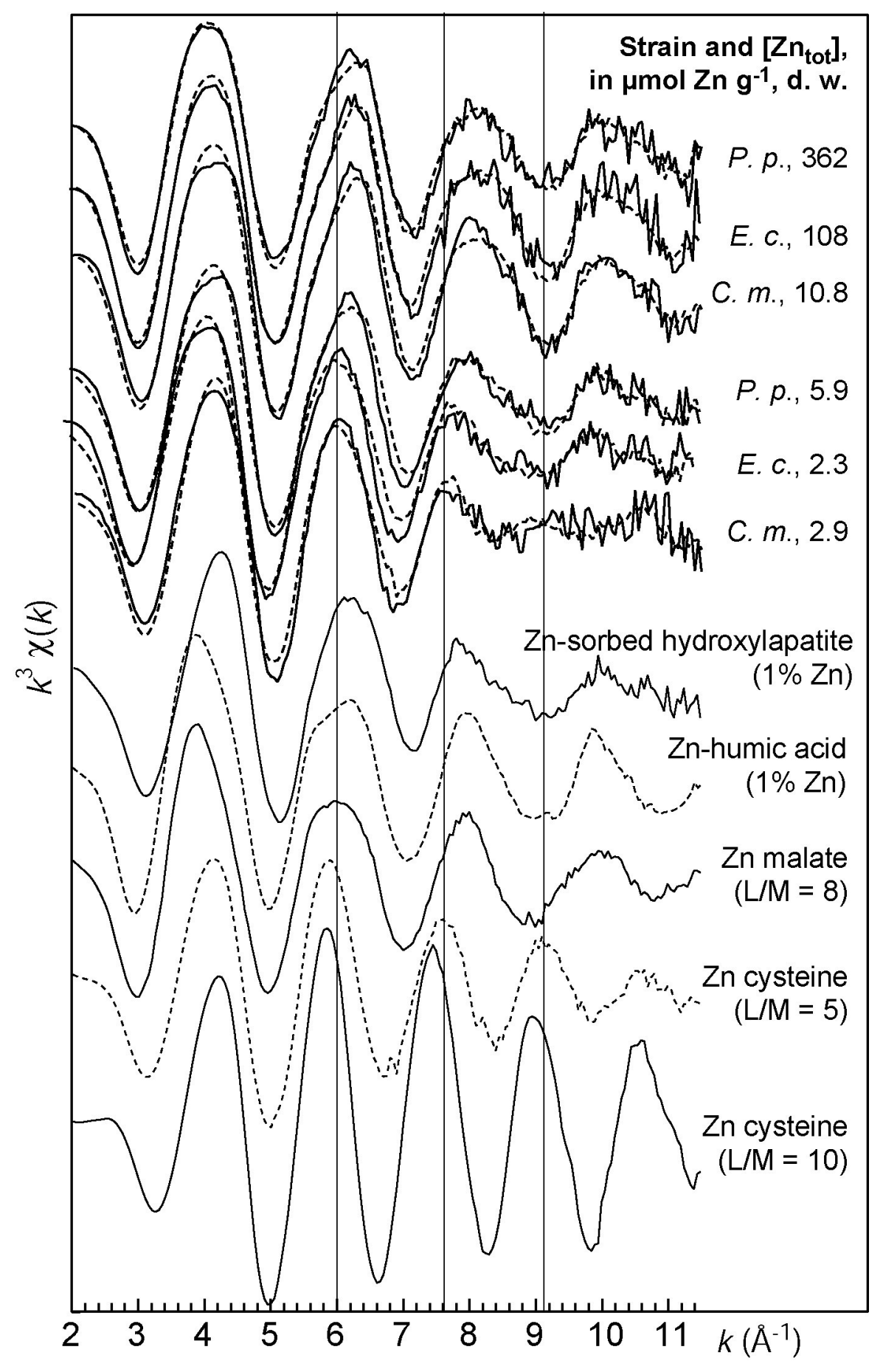

FIGURE 4 


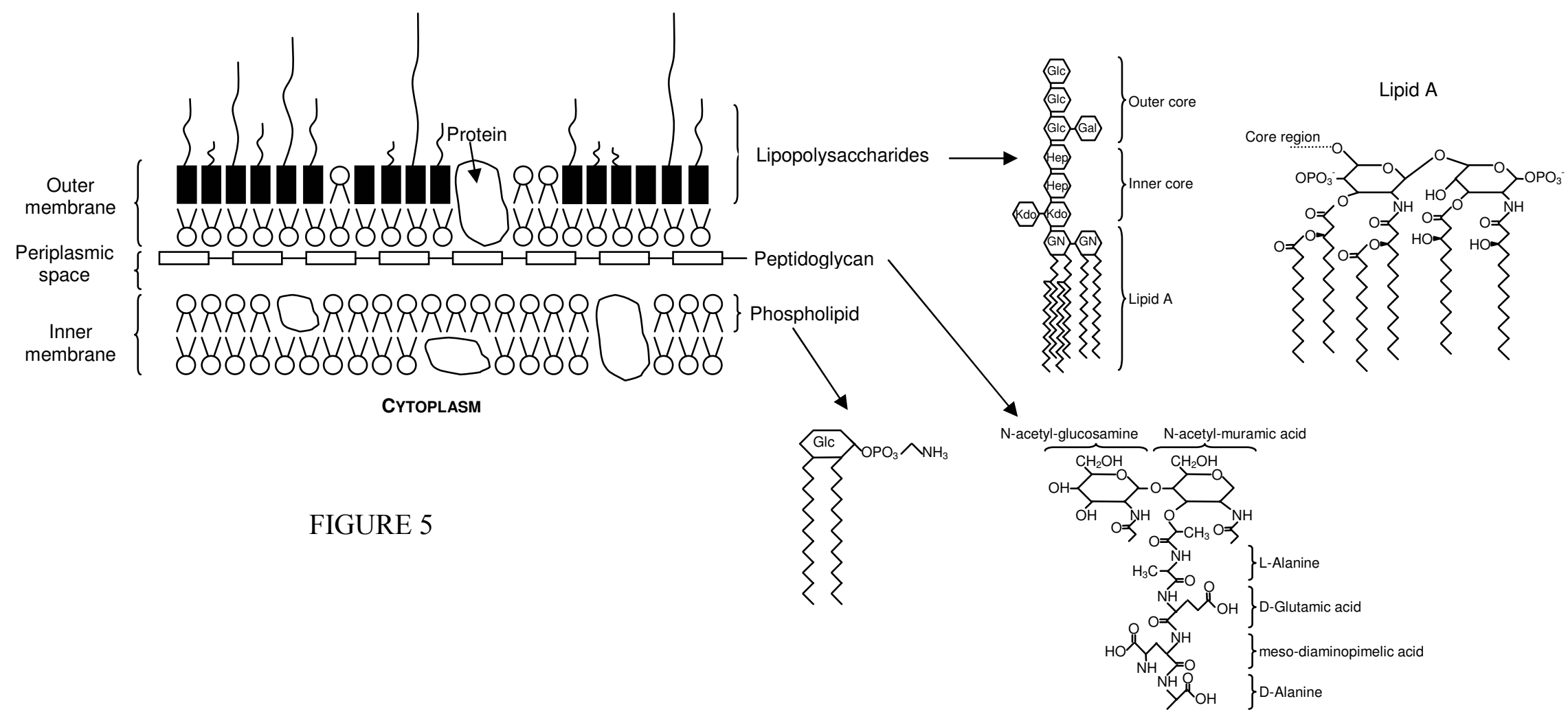

